Indonesian Journal of Nutrition and Dietetics Vol. 6, Issue 1, 2018: 1-6
Available online at: http://ejournal.almaata.ac.id/index.php/IJND DOI : http://dx.doi.org/10.21927/ijnd.2018.6(1).1-6

\title{
Effect of loloh sembung (Blumea balsamifera) maturity stage on antioxidant activity
}

I Gusti Ayu Wita Kusumawati ${ }^{*}$, I Nengah Reyunika1 ${ }^{1}$, Ida Bagus Agung Yogeswara ${ }^{1,3}$, I Gede Mustika ${ }^{1}$, I Made Wisnu Adi Putra', Umar Santoso², Yustinus Marsono²

${ }^{1}$ Faculty of Health Science and Technology, Universitas Dhyana Pura

Jalan Raya Padang Luwih, Tegaljaya, Dalung, Dalung Kuta Utara, Badung, Bali 80361, Indonesia, Telephone: (0361) 426450

${ }^{2}$ Faculty of Agiculture of Technology, Universitas Gadjah Mada

Jalan Flora No. 1 Bulaksumur, Sleman, Yogyakarta 55281 Indonesia, Telephone (+62 274) 589797, Fax (+62 274) 589797

${ }^{3}$ Faculty of Food Biotechnology, University of Natural Resources and Applied Life Sciences BOKU Wien, Austria, Gregor Mendel Strasse 33,1180 Phone (+43) 476540

*Corresponding author: witakusumawati@undhirabali.ac.id

\begin{abstract}
ABSTRAK
Latar belakang: Loloh sembung (Blumea balsamifera) adalah minuman tradisional masyarakat Bali yang digunakan untuk mengobati penyakit. Perbedaan kematangan daun sembung akan mempengaruhi aktivitas antioksidan loloh sembung.

Tujuan: Penelitian ini bertujuan untuk menentukan aktivitas antioksidan loloh sembung yang dibuat dari berbagai jenis kematangan daun sembung yang diekstrak dengan menggunakan pelarut air.

Metode: Serbuk daun sembung pada tingkat kematangan yang berbeda (muda, dewasa dan tua) direbus untuk menghasilkan loloh sembung. Analisis kandungan antioksidan meliputi analisis total fenolik, total kandungan flavonoid dan aktivitas antioksidan ferric reducing antioxidant power (FRAP).

Hasil: Hasil analisis menunjukkan bahwa daun sembung dengan tingkat kematangan tua menunjukkan kandungan total fenolik dan aktivitas antioksidan yang tinggi dibandingkan dengan daun dewasa dan muda, yaitu masing-masing sebesar 0,85 $\pm 0,005 \mathrm{GAE} / \mathrm{g}$ dan 0,66 $\pm 0,003 \mathrm{mmol} \mathrm{Fe}{ }^{2+} / \mathrm{g}$ sampel. Sedangkan, daun dengan tingkat kematangan dewasa menunjukkan total flavonoid yang tinggi, yaitu sebesar 0,39 $\pm 0,006$ QE/g. Berdasarkan korelasi Pearson, perbedaan tingkat kematangan daun menunjukkan korelasi positif dengan kandungan total fenolik, total flavonoid dan aktivitas antioksidan (FRAP).

Kesimpulan: Perbedaan tingkat kematangan daun sembung menunjukkan korelasi positif dengan kandungan total fenolik, total flavonoid dan aktivitas antioksidan (FRAP). Penelitian ini menunjukkan bahwa loloh sembung berpotensi sebagai minuman fungsional yang memanfaatkan kearifan lokal.
\end{abstract}

KATA KUNCl: tingkat kematangan daun, total fenolik, total flavonoid, FRAP

\begin{abstract}
Background: A Loloh sembung (Blumea balsamifera) is a traditional herbal drink from Bali and widely used to treat several diseases by Balinese people. Sembung leaf at different maturity stages would affect antioxidant activity of loloh sembung.

Objectives: The objective of the research was determined antioxidant activity of loloh sembung prepare from different maturity stages of sembung leaf and extracted using water.

Methods: Sembung leaves powder at different maturity stages (young, mature and old) was boiled to produce loloh sembung. The analyses of antioxidant activity of loloh sembung included total phenolic content (TPC), total flavonoid content (TFC) and ferric reducing antioxidant power (FRAP).

Results: The results showed that old leaves were significantly higher in TPC and FRAP values compare to mature and young leaves, i.e $0.8575 \pm 0.005 \mathrm{GAE} / \mathrm{g}$ and $0.6625 \pm 0.003 \mathrm{mmol} \mathrm{Fe} \mathrm{F}^{2+} / \mathrm{g}$ sample respectively. However, the mature leaves revealed significantly high TFC, i.e 0.3972 \pm 0.006 QE/g. Based on Pearson's correlation coefficient, the difference of maturity stage exhibited positive correlation with TPC, TFC and FRAP.
\end{abstract}


Conclusion: The different of maturity stage exhibite showed positive correlation with TPC, TFC and FRAP. This study suggested that loloh sembung had a promising prospect as functional drink based on local wisdom.

KEYWORDS: leaf maturity stage, loloh sembung, total flavonoids, total phenolic (italic)

\section{INTRODUCTION}

Sembung is a medicinal herbal plant that is widely used to treat several diseases in a traditional community of Southeast Asia (1). Recent study reported that sembung is commonly used to aid postpartum recovery, high antioxidant activity and ACE inhibitory activity $(1,2,3)$. The beneficial effect is due to high flavonoid content in sembung. Various flavonoids have been isolated from the leaves and these flavonoids responsible for antioxidant activity, ACE inhibitory activity, anti-inflammatory activity and sudorific properties $(4,2,3)$. Previous studied by Ali et al (2005) reported that new constituents of flavonoids 3,4,5-trihydroxy-3,7-dimethoxyflavanone,3,4,5trihydroxy-7-ethoxyflavanone and new biflavonoid, 3-0-7-biluteolin have been successfully isolated from sembung leaves using soxhlet extraction methods (4).

Consumption of herbal medicine in Balinese community has long been used as traditional remedies. This tradition has been passed down to generations. Sembung is commonly consumed as herbal drink (Ioloh) by Balinese people and several methods such as boiling and kneading by hand are employed to produce loloh sembung. Our previous studied Kusumawati and Yogeswara (2016) reported that different extraction methods exhibited various antioxidant capacity, phenolic content and flavonoid content in loloh sembung (3). Some old leaves are commonly used to produce loloh sembung and the maturity stage of the leaves gives a significant impact on bioactive compounds of loloh sembung.

Different maturity stage of the leaves plays significant role on bioactive compounds in plant extract $(5,6)$. Norlham et al (2015) reported that young Cosmos caudatus leaves exhibited high antioxidant activity compare to old and mature leaves. This result was in agreement with Yun et al (2014), it reported that old blueberry leaves exhibit high phenolic content (5). In addition, Morales et al (2017) have revealed that phenolic compound of Hovenia dulcis pseudofruit have increase through the maturity process (7). A high phenolic compound in the leaves has strongly correlated with the antioxidant activity (8). However, there is a little information regarding the effect of maturity degree on antioxidant capacity of loloh sembung be. Therefore, the aim of this study was to determine the antioxidant capacity of sembung leaves at different maturity stages to produce loloh sembung.

\section{MATERIALS AND METHODS}

Sembung fresh leaves (young, mature and old) that seen at Figure 1 were collected from Tabanan, Bali, Indonesia and were harvested in March 2017. The young leaf is leaf primordium nearby the stem tip that have most epidermal hairs; the mature leaf is bifacial leaf that have less epidermis hair; the old leaf is
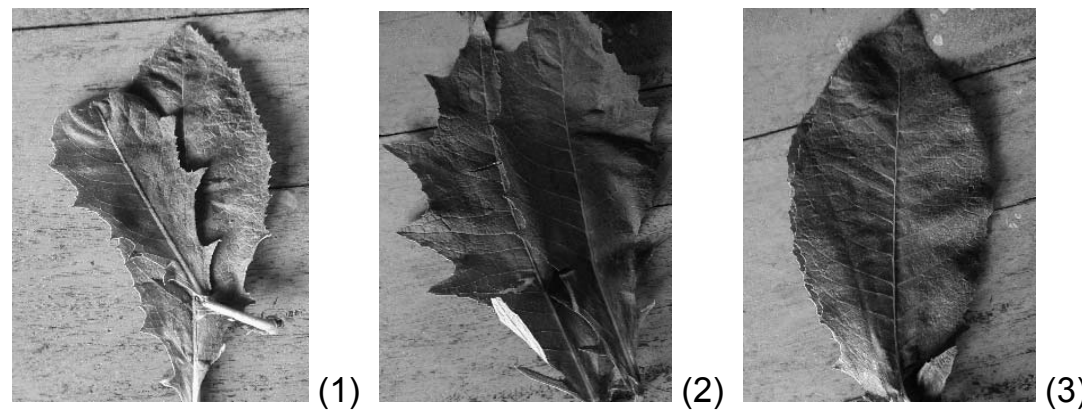

Figure 1. Sembung leaf (1) young; (2) mature; (3) old 
have not epidermis hair (9). The leaves were collected and identified in Plant Taxonomy Laboratory, Faculty of Biology, Udayana University, Bali. Folin-Ciocalteu, methanol, ethanol and sodium carbonate (analytical grade, Merck), gallic acid, quercetin, alumunium chloride, 2,4,6-Tri(2-pyridyl)-s-triazine (TPTZ), $\mathrm{Fe}_{2} \mathrm{SO}_{4} \cdot 7 \mathrm{H}_{2} \mathrm{O}$ were purchased from Sigma-Aldrich chemical and aquades.

\section{Preparation of loloh sembung}

Sembung leaves at different maturity stages were washed, rinsed and dried under the shade. Subsequently, the leaves were pounded into a powder with a blender (Phillips) and sieved it into 80 mesh. Sembung leaves were collected and divided into three parts i.e young, mature and old leaves. The leaves were washed, rinsed and drye under the shade for fourteen days. Dry leaves were pounded with a blender and sieved into 80 mesh to obtain sembung powder. Dried sembung powder $(7 \% \mathrm{w} / \mathrm{v})$ was boiled for seven minute to produce loloh sembung.

\section{Antioxidant capacity}

A ten microliter of extract were dissolved in 30 $\mu \mathrm{l}$ of distilled water and thoroughly mixed with $200 \mu \mathrm{l}$ FRAP (mixture of iron chloride and 2, 4, 6 - tripyridyl - $s$ - triazine). The aliquots were incubated for 4 minutes in room temperature and the absorbance were measured with spectrophotometer UV-Vis and was read at $600 \mathrm{~nm}$. FRAP value was expressed as $\mathrm{Fe}^{2+}$ equivalent in $\mathrm{mmol} \mathrm{Fe}^{2+} / \mathrm{g}$ dried extract. (10)

\section{Total phenolic content}

Determination of phenolic content was measured using Follin ciocalteau methods with slight modification. Gallic acid was used as a standard. Fifty $\mu \mathrm{l}$ (extract sample) was mixed with $250 \mu \mathrm{l}$ Follin ciocalteau and incubated for 1 minute. Briefly mixed with $750 \mu \mathrm{Na}_{2} \mathrm{CO}_{3} 20 \%$ and vortex for 1 minute and followed by incubation in room temperature for 2 hours. Extract sample were then added with $5 \mathrm{ml}$ of aquades and the absorbance were read at 760 $\mathrm{nm}$. Phenolic content value was expressed as gallic acid equivalent/g dried extract (11).

\section{Total flavonoid content}

A $50 \mu \mathrm{l}$ extract were mixed with $4 \mathrm{ml}$ aquades and $0.3 \mathrm{ml} \mathrm{NaNO}, 10 \%$ and incubated in room temperature for 6 minutes. After 6 minutes, distilled water was added until reach final volume of $10 \mathrm{ml}$ and followed by vortexing for 1 minute. Subsequently, the mixture was kept for 15 minutes. Absorbance was read at $510 \mathrm{~nm}$ and distilled water was used as a blank. Quercetin was used as a standard and flavonoid was expressed as Quercetin equivalent/ dried extract (12).

\section{Statistical analysis}

All experiments were conducted in triplicated and the results were expressed as mean \pm standard deviation. Two-way analysis of variance (ANOVA) of the data was carried out using SPSS 20.0 software. Mean differences were established by the Tukey's range tests. The significant differences $(p<0.05)$ between the means were performed to determine the effect of stage maturity on the TPC, TFC and FRAP of loloh sembung.

\section{RESULTS}

The results of this study exhibited that loloh sembung prepare from different maturity stage have different total phenolic, flavonoid and antioxidant capacity (FRAP methods), as presented in Table 1.

Table 1. Total phenolic, flavonoid and antioxidant capacity (FRAP methods) of loloh sembung prepare from different maturity stage

\begin{tabular}{lccc}
\hline $\begin{array}{c}\text { Maturity } \\
\text { stage }\end{array}$ & $\begin{array}{c}\text { Total Phenolic Content (TPC) } \\
\text { (mgGAE/g sample) }\end{array}$ & $\begin{array}{c}\text { Total Flavonid Content (TFC) } \\
\text { (mgQE/g sample) }\end{array}$ & $\begin{array}{c}\text { Antioxidant Capacity FRAP } \\
\text { (mmol FeE/g sample) }\end{array}$ \\
\hline Young & $0.38 \pm 0.004^{\mathrm{a}}$ & $0.13 \pm 0.003^{\mathrm{a}}$ & $0.65 \pm 0.002^{\mathrm{b}}$ \\
Mature & $0.81 \pm 0.005^{\mathrm{b}}$ & $0.40 \pm 0.006^{\mathrm{c}}$ & $0.63 \pm 0.003^{\mathrm{a}}$ \\
Old & $0.86 \pm 0.005^{\mathrm{c}}$ & $0.32 \pm 0.005^{\mathrm{b}}$ & $0.66 \pm 0.003^{\mathrm{c}}$ \\
\hline
\end{tabular}

*Different letter in the same coloum indicates significant difference $(p<0.05)$ 


\section{DISCUSSION}

\section{Yield of loloh sembung}

The yield extract from young, mature and old leaves obtained in this study was $9.21 \%, 16.78 \%$ and $12.95 \%$ respectively. Differences in yield extraction was due to young leaves content less water compare to mature and old leaves. Biochemical properties of the stomata in each mature stages effect the water content in plant leaves (13). Boiling method was employed to produce loloh sembung by using 100 $\mathrm{ml}$ of distilled water at $80^{\circ} \mathrm{C}$ for 7 minutes, since this method was commonly used by the Balinese people to produce loloh sembung (14). Total phenolic content, flavonoid content and FRAP analysis were carried out to determine the antioxidant activity of loloh sembung.

\section{Total phenolic content}

The total phenolic content in loloh sembung ranged from $0.38 \pm 0.004$ to $0.86 \pm 0.005 \mathrm{GAE} / \mathrm{g}$ respectively. The results showed that old leaves contained high phenolic content $0.86 \pm 0.005 \mathrm{GAE} / \mathrm{g}$. The phenolic content of the leaves were increased through the maturity process while the young and mature leaves exhibit low total phenolic content. All samples showed significant TPC according to Tukey test as can be seen in Table 1 .

This studied were in agreement with several researches reported that a number of old leaves exhibit high total phenolic content while young and mature leaves exhibit low total phenolic content. High total phenolic content in old leaves were due to optimum synthesis of phenolic compound through aging process. The maturity of the leaves was also effect the production of secondary metabolite and total phenolic content. Thus, the older leaves reflect high TPC compounds compare to young and mature stages present in the sample. Maieves et al (2015) reported that total antioxidant capacity has closely related with total phenolic content (15).

\section{Total flavonoid content}

The total flavonoid content in loloh sembung ranged from $0.13 \pm 0.003$ to $0.32 \pm 0.005 \mathrm{QE} / \mathrm{g}$ respectively. These results showed that mature leaves exhibit high flavonoid content present in the sample. Whereas, young leaves and old leaves showed lower total flavonoid content in the extract sample. Previous studied by Oleyade et al (2012) reported that mature leaves seem to exhibit high flavonoid content compare to young and old leaves (16). High flavonoid content is probably due to the alteration of bioactive compounds in the leaf tissue during maturity process. Mature leaves exhibit low phenolic content and yet, exhibit high flavonoid content. High flavonoid content is also due to high absorption of the mature leaves to the sunlight which may lead to over synthesis of flavonoid compound. Mature leaves have a wider surface area and hence have a high absorption ability to the sunlight compare to young and old leaves (17).

In contrast, different results were reported by other studied $(6,18,19)$ that flavonoid content were increased in young leaves compare to mature and old leaves. This result suggests that different type of leaves exhibit various phenolic content at different maturity stages.

\section{Antioxidant capacity}

In biological tissues, mechanisms of their antioxidant are extremely complex (20). In this study, the antioxidant capacity of loloh sembung was evaluated using FRAP method. The antioxidant activity by FRAP in loloh sembung ranged from $0.65 \pm 0.002$ to $0.66 \pm 0.003 \mathrm{mmol} \mathrm{Fe}^{2+} / \mathrm{g}$ sample respectively. This result showed that old leaves exhibit high antioxidant capacity $0.66 \pm 0.003 \mathrm{mmol} / \mathrm{g}$ sample. Tukey test analysis showed that all samples have a significant antioxidant capacity

These results were in agreement with Kamal et al (2012) reported that old leaves exhibit high antioxidant capacity analyzed using FRAP method (17). The antioxidant capacities are relatively increased with plant maturity. During maturity process, the bioactive compound is increasing and depend on the biosynthetic pathways and mechanisms of metabolic control.

There was a highly significant $(p<0.01)$ positive correlation between the maturity stage and TPC value in loloh sembung (Pearson $R=0.91$ ), TFC value (Pearson $R=0.71$ ), as well as antioxidant 
capacity (FRAP) value in loloh sembung (Pearson $R=0.26)$. The results indicate that maturity stage affected to total phenolics contents, total flavonoid contents and antioxidant capacity.

Sembung leaf has high flavonoid content and widely distributed in plants. Flavonoid is a polyphenolic compounds and possess antioxidant activity in biological activity $(21,22)$. Flavonoids exhibit various biological effects including antibacterial activity, anti-inflammatory and antiallergic. Flavonoids act as antioxidant by chelating reactive oxygen species and lead to inhibition of enzymes responsible for superoxide anion production. Resulting prevention of radical alkoxyl and peroxyl radicals formation (23).

\section{CONCLUSIONS AND RECOMMENDATION}

As a conclusion, old sembung leaves exhibit high phenolic content and high antioxidant capacity while mature sembung leaves showed high flavonoid content. Hence, mature sembung leaves can be utilized to produce loloh sembung with a high flavonoid content. Therefore, loloh sembung with its high flavonoid content may be considered to have the ability such as antibacterial, anti-inflammatory, vasodilatory and anticancer.

\section{Acknowledgements}

The author would like to thank KEMRISTEKDIKTI for their financial aid through PEKERTI research grant.

\section{REFERENCES}

1. De Boer, H.J., and Cotingting, C. 2014. Review: Medical plants for women's healthcare in southeast Asia: A meta-analysis of their traditional use, chemical constituents, and pharmacology. Journal of ethnopharmacology, 151: 747-767.

2. See, G.L.L., Arce, F.V.Jr., Deliman., and Yolanda C. 2016. ACE (Angiotensin Converting Enzyme) inhibition activity of oven-dried and air-dried sambong Blumea balsamifera L.(dc.) Tea. International Journal of Pharmacognosy and Phytochemical Research, 8(7): 1132-1136.
3. Kusumawati, I.G.A.W and Yogeswara,I.B.A. 2016. Antioxidant capacity and antibacterial of loloh sembung based on extraction methode. Medicine Traditional Journal, 21(3): 143-148.

4. Ali, D.M.H., K.C. Wong., and P.K. Lim. 2005. Flavonoids from Blumea balsamifera. Fitoterapia $76: 128-130$.

5. Yun D, Gaiyun $Y$, Jin $Y$, Bingjun Q, Zhenmin L, Danfeng W, Yun Z , and Yanyun Z. 2014. Influences of ripening stages and extracting solvents on the polyphenolic compounds, antimicrobial and antioxidant activities of blueberry leaf extracts. Food Control, 38: 184-191.

6. Norlham.A, Dian N, Kherni, Nooraaln, Asisah, 2015. Influences of Maturity Stages and Extraction Solvents on Antioxidant Activity of Cosmos Caudatus Leaves. International Journal of Research Studies in Biosciences (IJRSB), 3(12): 1-10.

7. Morales, P., Helayne, A.M., Maria, I.D., Ricardo, C.C., Maria C.S-M., Celestino, S-B., Lillian, B., and Isabel, C.F.R.F. 2017. Hovenia dulcis Thunb. Pseudofruits as functional foods: Phytochemicals and bioactive properties in different maturity stages. Journal of Functional Foods, 29:37-45.

8. Gurjar, M. S., Ali, S., Akhtar, M., and Singh, K.S. 2012. Efficacy of plant extracts in plant disease management. Agricultural Sciences, $3: 425-433$.

9. Liu, L., Xiaolu C., Quan Y and Yuxin P. 2016. Morphological development of Sambong (Blumea balsamifera (L.) DC.) leaf studied by frozen section and thin section. Journal of Biosciences and Medicines, 4:10-13. http:// dx.doi.org/10.4236/jbm.2016.44002.

10. Konczak,I., Dimitros,Z., matthew, D., and Patricia A., 2010. Antioxidant capacity and phenolic compounds in commercially grown native australian herbs and species. food chemistry, 122: 260-266.

11. Ammar, I. Monia E., and Hamadi A. 2015. Phenolic content and antioxidant activity of cactus (Opuntia ficus-indica L.) flowers are modified according to the extraction method. Industrial crops and products. 64 : 97-104 
12. Chang, C.C., Yang, M.H., Wem, H.M., and Chern, J.C. 2002. Estimation of Total Flavonoid Content in Propolis by Two Complementary Colorimetric Methods, Journal of Food and Drug Analysis, 10, 3 : 178-182

13. Choluj,D., R. Karwowska, M. Jasińska, and G. Haber. 2004. Growth and dry matter partitioning in sugar beet plants (Beta vulgaris L.) under moderate drought. Plant Soil Environ., 50 (6): 265-272.

14. Kusumawati, I.G.A.W., Darmawijaya, I.P., and Yogeswara, I.B.A. 2014. Potensi antioksidan loloh tempuyung (Sonchus arvensis $L$.) sebagai minuman fungsional. Prosiding Seminar Nasional Biologi FMIPA UNHI.

15. Maieves, H.A., Lopez-Froilan, R., Morales, P., Perez-Rodriguez, M.L., Ribani, R.H., Camara, M. 2015. Antioxidant phytochemicals of Hovenia dulcis Thunb. Peduncles in different maturity stage. Journal of functional foods, 18: 1117-1124.

16. Oloyede F.M, Oloyede F. A. And Obuotor E. M, 2012. Effect of Plant Maturity on the Antioxidant Profile of Amaranthus cruentus L. and Celosia Argentea L.. Bulletin of Environment, Pharmacology and Life Sciences, 2(2): 22771808.

17. Kamal U, Abdul S.J, Md. Eaqub A and Mohd R.I. 2012. Evaluation of Antioxidant Properties and Mineral Composition of Purslane (Portulaca oleracea L.) at Different Growth Stages. Molecular Sciences, Volume 13, pp. 1422-0067.

18. Abdulaziz Rabiu Abdulkadir, Md. Sarwar Jahan and Dhiya Dalila Zawawi, 2015. Effect of chlorophyll content and maturity on total phenolic, total flavonoid contents and antioxidant activity of Moringa oleifera leaf (Miracle tree). Journal of chemical and pharmaceutical reseach, 7(5), pp. 1147-1152.

19. Bini $W$, , Qingyuan $H$, Chandrasekar $V$, Hongkang C, Hui G, Ni C, Wei C, Xingang L, and Zhongli., 2016. Changes in phenolic compounds and their antioxidant capacities in jujube (Ziziphus jujuba Miller) during three edible maturity stages. LWT Food Science and Technology, 66(1), pp. 56-62.

20. Carocho, M and Ferreira, I.C.F.R. 2013. A review on antioxidants, prooxidants and related controversy: Natural and synthetic compounds, screening and analysis methodologies and future perspectives. Food and chemical toxicology, 51: 15-25.

21. O'Byrne DJ, Devaraj S, Grundy SM, and Jialal I. 2002. Comparison of the antioxidant effects of Concord grape juice flavonoids alpha-tocopherol on markers of oxidative stress in healthy adults. American Journal Clinical Nutrition 76(6): 13671374.

22. Bae, H. et al., 2012. Extraction efficiency and validation of an HPLC method for flavonoid analysis in peppers. Food Chemistry, 130(3), pp.751-758. Available at: http://dx.doi. org/10.1016/j.foodchem.2011.07.041.

23. Biesaga, M., 2011. Influence of extraction methods on stability of flavonoids. Journal of Chromatography A, 1218(18), pp.25052512. Available at: http://dx.doi.org/10.1016/j. chroma.2011.02.059. 